هجلة الغنون والادب وعلـور الإنسانـيات والاجتهــاع

Journal of Arts, Literature, Humanities and Social Sciences www.jalhss.com ISSN online: 2414-3383 ISSN print: 2616-3810

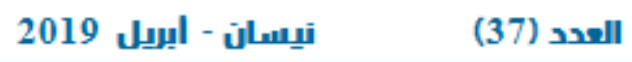

\title{
D.H. Lawrence and Modernity \\ (A study and analysis in the Last Poems)
}

\author{
Mohammed Abdulhussein Muneer \\ DG of Education in Babel
}

\begin{abstract}
This research high lights on D.H. Lawrence's antagonism to modernity. Lawrence throughout his Last Poems reveals his rejection to modern life and his connection to the past. The research concentrates on the comparison between the modern life and ancient civilization. Thus, in this research, we are invited to see Lawrence's point of view towards nature in modern life, human's manner of life, the kind of cities, and the deep details in life are shown completely opposite to what was in the past. Also it takes into consideration a comparison between modern and old religions showing out some similarities and differences. The research is composed of two sections; the first is entitled "D.H. Lawrence's opinion towards Modernity", which shows, throughout a comparison, the differences between two civilizations. Section two is entitled " Wheel Theory and Evil Poems" which discusses the reason, to modern life, of being bad comparing with the old life. This research talks about modernity and ancient civilizations in some of the Last Poems that are written in Lawrence's last period of life.
\end{abstract}


(37) (37)

2019 iيnان - ايرِي

مجلة الفنون والندبوعاوم الإنساتيات والاجتهاع

\section{I- Introduction}

This research is concerned with one of the problems that Lawrence criticizes very much, especially in his Last Poems, i.e modern life and his hostility to it. From the first reading, it is obvious how much his point of view contrasts to some extent modernity. Not just Lawrence attacks modern life, but, as Mr. Ramish Karki, mentions Lawrence shares that with Alexander Pope and Jonathan Swift in attacking the barbarous and the absurd of modern civilization. He attacks everything in the world which separates man from his "animal delights. (Karki, p. 244) There are many reasons behind his antagonism to modern life and as a result to modern man. In this research the discussion will deal with modern life and Lawrence's criticism of it. Moreover the research will take into consideration the kinds of modern evil or as it is described evil world soul. And the kinds of evil will receive a vital attention in this research.

Lawrence attacks the modern life in his poem "In the Cities" (Pinto and Roberts, 1995, pp. 703-04), and sheds light on the negative side of modernity and ignores its positives. In this poem, Lawrence says that the modern cities are polluted and dirty:

"In the cities

there is even no more any weather

the weather in town is always benzine, or else petrol

fumes

lubricating oil, exhausted gas

as over some dense marsh, the fumes

thicken, miasma, the fumes of the automobile

densely thicken in the cities". (lines 1-8).

"Lawrence heaven is a world away from 'factories, jazz, cinemas' chiefly. It is placed preferably in luxuriant semi-topical parts of the earth where the sun and moon are brilliant." Fundamentally, where the cities are not cities but small countrysides and towns, un-modern, where the inhabitants are "members of dark-coloured aboriginal race not too buttoned up in conventional clothing." They are a mixed group of "brilliant sun, bodies, desert places, [in the ] intense dark" (Potter. P. 27). These bad 
العدد (37)

2019 نِيسان - ايِريل

مجلة الفنون والندب وعلوم الإنسانيات ولاجتهاع

features of the modern cities lead the persona to criticize them because they cause unhealthy life and diseases to inhabitants, they have the soul and mind illness. In such places the "Satan is dwelled, fair, and civilized". (Potter. P. 27). Moreover, Lawrence, as always in the Last Poems, uses the opposite imagery to deny the first imagery. Here, Lawrence compares the modern life with the old civilizations, his favorite period to shed light on : "In ancient Rome, down the thronged streets/no wheels might run, no insolent chariots./Only the footsteps, footsteps of people" (lines 9-12).

Old cities are pure and not disturbed by the "wheels". Modern Life kills the beauty of natural life in the cities. Ancient Romans were walking with bare feet that their "footsteps" are left on the ground, they were naked men, which is symbolic of the difficulties of modern life.

The old cities like "Minos" the civilization of the Minosians are of "Minos" the king of Crete, Zeus and Europa's son, after his death. It is believed that this civilization feeds the Greek imagination about Crete civilization. "Mycenae", Mycenaean shows the last phase of the old Bronze Age in Ancient Greece (ca. 1600-1100 BC). These two cities are the poet's example of the old civilizations, in which life is normally going on, the creatures are moving normally, nothing threatening them, the "lion" of the wood, may refer to Dionysus who was the leader or lord of nature. This god sacrifices the sacred animals to renew the world, the nature and even himself.

Lawrence does not just give an example for the ancient and favorite cities but comparing these cities with the largest and biggest cities in the modern life. The dead of modern life are "tread[ed] heavily" because of the unclean air of the industries and factories that change and polluted the air.

Lawrence's anxiety about Victorian England and the pollution and squalor caused by the Industrial Revolution is shared by the novelist Dickens where he depicts the miserable ambience at the time.

The modern cities have been corrupted and ruptured souls, modern man is degenerate because he has personalized everything in the universe of "the mire of fumes", otherwise the pagan is not, he left his partially little ego out of the representation, creating real, vital connections to the cosmos.

The second and the third stanzas of "The Greek Are Coming" (Pinto and Roberts. P.687) depicts contrasted images of the old and the modern ships, which come in detail later; here Lawrence prefers the old ships more than the modern ships. In the last stanza he criticizes the modern ones by saying: "an ocean liner . . . leaving 
العدد (37)

2019 نِيسان - ايِريل

مجلة الفنون والندبوعاوم الإنسانيات والاجتهـاع

a long threaded of dark smoke", (lines, 9-10). Moreover, he makes a difference between the ships which sail to the east, and modern ships "going east", (line, 9). Noticeably, most of the return gods in the Last Poems return by their ships using the sea, which is the link of the past. The sea is constantly used to represent the unchanging and anonymous supreme power of nature. The individual is lost in its infinity. History comes and goes in brief lives, represented by boats.

In the next part of the poem, "Middle of the World"( Pinto and Roberts. P.688), Lawrence shows the modern ships and the differences between the ancient and modern life. He is criticizing the modern world and preferring the old, 'the Greeks world'. When he says that these kinds of modern ships cross like a "clock-work", and "they only cross", they are nothing important and they do not arouse the feeling.

These modern ships are smoky and smell terrible, and according to Lawrence, are ugly in comparison to the old ones. But the P. \& O. and Orient Line ships can never change "the Minoan distance," the mysterious things, appropriately associated with the vanished civilization of Crete.

\section{II- Wheel Theory and Evil poems}

Evil is an aspect that is known in the old cultures, and modern cultures as well, opposite to good. For instance, it is clearly used by religious men and mentioned many times in terms of warning from being bad, and sometimes it takes, in religion contexts as a supernatural force figure. And it takes the form of Satan.

Nevertheless, man who evilly acts, or to some extent he himself the Evil, or follows Evil, they will lose everything and they will be the great losers. That is because according to the Islamic and other religions ethics, they will reward the immortality in the hell.

This subject, in the Bible, takes an important field. It argues: to "Turn away from evil and do good; so shall you dwell forever." (Psalm, 37:27). Wherever man is, he has to do good and ignore Evil because of the belief that every man is rewarded after his resurrection according to his goodness or badness in life. "And (to) be steadfast in prayer and regular in charity: And whatever good ye send forth for your souls before uoy, ye shall find it with Allah: for Allah sees all that ye do."( Ali, verse 110) Quran, and other holy books, like Torah, and the Bible, deals with life after 
death as a day of judgment by the God, Allah, and everyone will get his reward due to his good or bad actions before death.

So, the concept of judgment after life is not going well with Lawrence but he believes the life of freedom of souls in deep darkness which is described by Lawrence as oblivion.

That gives an idea of the differences between the two beliefs: Lawrence believes in the body resurrection, which, traditionally, derives from the ancient civilization, and the modern religions believe in the resurrection of souls without bodies, thinking the material things do not resurrect and the punishment and reward will be for the souls rather than bodies. For Lawrence, to follow the tradition, it does not mean that the dead are alive but the alive are dead.

In these poems he picks up the theme concerning the place of the evil or evil's home. In these poems, as described by Aldington,

[Lawrence] was troubled by thoughts of "the evil world soul" which had become so hideously triumphant. But now all other themes faded from him, his dreams of the ancient gods, imaginings of Cretans and man of Tiryns, ... . his delight in the morning and evening, sun and moon, ... . his grief at the greyness of the world of the mechanical living, all faded in the vision of death. (Aldington, 1950, p.350)

Lawrence takes personally the problem of "the evil world soul" which leads him to have a negative point of view toward the modern life, as anti-nature, and he highly criticizes modern man. In this discussion we may ask: What is Evil? And where does it dwell? Throughout these poems Lawrence depicts more than one imagery of Evil trying to exemplify his opinion towards modern man as one of the main subjects illustrated in the Last Poems.

Lawrence starts with rhetorical sentence, he says that no one will fall with "Satan", alone "he only fell", since "the Lord Almighty, . . . a bit beyond himself". The main predominant theme is the evil soul "Satan", and how to fall from the high side of god. May be the fall here represents those modern people who, according to Lawrence, are conscious of their attitude and thoughtfully aware. He describes modern man as a "Satan", an evil, whose importance lies in scaling life, because life, as traditionally believed, "balanced" by two opposite features. Lawrence also depicts the image of "hell" by referring to "Satan", and to those modern people as "lost souls". 
(37) (37)

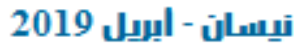

Lawrence's tone is affiliated more with the Quran mood which is speaking on behalf of "Satan": "And surely I (the Satan) will lead them [mankind] astray and surely I will arouse desire . . . " (An-Nisa Surah: verse. 119). The religious interpretation he has gained in his early life leads him to think about Satan in this sense to represent the men who are lost in life.

The "lost souls", described as "Satan", are opposite to "heaven" do "the balance of life". This balance according to the ancient cannot happen without the two opposite features. "The opposite tension" which is defined by Burnet as proclaimed by Herakleitos that:

The world is at once one and many, . . . and it is just the "opposite tension" of the opposites that constitute the unity of the one, . . It was safest to unite these two things, ... and is kept together by Hate and Love" (Burnet, p.106)

Continually, these opposites can save the life balance though they can be considered two directions of one thing as a correlation of opposites. Burnet says that the Herakleitean asserts this fragment. He said "the clue to their meaning is to be found in the account already given of the assertion that day and night are one, which does not mean that] day was night, or night was day, but they were two sides of the same process". ( Burnet, p. 118) According to this clue we cannot talk about night and ignore the day, they are taken equally and oppositely. We can also generalize this theory to all things around us. For instance, we cannot feel the cold if there is no heat, and vice versa. And the same thing applies to the opposites of evil and good.

In spite of being a world of two opposite things like "Kissing and Horrid Strife, united in one world, they, according to Lawrence, "swing against each other" (line 14). And throughout the "swing" the balance of the world is created.

The matter of "Evil" is in contact with the theme of the poem "Doors".

The poet depicts the images of "dark doors" and "bright doors" to show both sides of life. Ones, who go through the "dark doors", "lost souls" as described in the poem 
(37) (37)

2019 iيnان - ايرِي

"When Satan Fell", where They fearfully pass. And others, opposite to "lost souls" persons, who go through the "bright doors", without a care in the world, "gaily".

The opposite imagery is juxtaposed in the last stanza to depict the image of balance of life:

"There is a double sacredness of doors.

Some you may sing through, and all the men hear,

but others, the dark doors, oh hush! Hush!

Let nobody be about! Slip in! go all unseen". (lines 11-14).

May be these doors are mentioned by Edith Hamilton:

"Wherever it [the heaven] was the entrance to it. It was a great gate of clouds kept by Seasons, within were gods' dwelling" (Hamilton, 1942, p.20).

These two kinds of "Doors" draw attention to the attitude of the poet dealing with the modern life of modern man. According to these "doors" people can be classified into unthinking, bright "souls" and thoughtful, dark "lost souls". and according to this classification, people will take, according to Hamilton, in the underworld two roads:

"The regions to the left [. . .] were ruled over by stern Rhadamanthus [. . .] who punished the wicked for their misdeeds" (Hamilton, 1942, pp. 334-35)

The ultimate place where Lawrence believes to be is the place of gods, heroes and poets. The poem ends with a very significant and unclear sentence, "But evil, is another thing! In another place". The poet solves this problem, of the place of the "evil" is in the next poem "Evil Is Homeless". 
العدد (37)

2019 iيسان - ايِّل

The poem "Evil is Homeless" clarifies and to shows the ambiguity of the previous poem and says that "evil has no home" (line 1). As it has been suggested before in this chapter, the purpose behind evil that depicted by Lawrence poems criticize the modern life as well as modern man. The modern life and the modern religions worked together to make man, according to Lawrence "the community is inhuman, or less than human" (Lawrence, 1995, p.71)

The absolute homeless, is Lawrence's idea that dominates the series evil poems. Evil is homeless but not in the modern man's soul. Paradoxically, according to Lawrence, this evil dwells in the modern men's souls or they create evil in themselves because of their weakness and fear of death. They are evil souls, "lost souls", who have no place but "hell". They are "souls lost in darkness".

In the next line, Lawrence shows that the opposite image to " souls lost in darkness", is "souls lost in light", which are dwelling in "heaven". Here, the condition for being in "light" or in "darkness" as Lawrence showed in Apocalypse, he says that man's nature of is "primal need" and the man originally like "the old-Adamic needs a man's soul to be, in his own sphere and as far as he attains it, master, lord, and splendid one" (Lawrence . 1995, p. 71) they have to be: " . . like Persephone, or Attis/there are souls that are at home in both homes." (lines 6-9).

In this sense Lawrence says:

Human's heart needs [. . . ] splendor, gorgeousness, pride, assumption, glory, and lordship [. . .]. We become alas, what we think we are, men have been depressed now for many years in their male and splendid selves, depressed into dejection and almost into dejection. Is not that evil? Then let men themselves do something about it. (Lawrence, 1995, p. 71)

Lawrence, in Apocalypse, sees the solution for Man, is that he should think in images, which are instinct with the emotional substance, according to him not images that are rationalized, reasonably linked, pointed toward a regular conclusion. For the pagan consciousness, god enters and permeates all matter, is "present in water and rock". 
Evil, as described by Lawrence, prevents man from being "supreme master", and giving him primal needs. Nowhere for evil to dwell in, is out of the lighten human body, like the old cultures gods like "Persephone" or "Attis". But evil has its home in the souls of "blind-colour" eyes. They could not enjoy the beauty of the "scarlet and purple flowers", that make their life dark, like "Dante".

Then Lawrence ends the evil poems series saying:

\begin{abstract}
"And men that sit in machines
among spinning wheels, in an apotheosis of wheels

sit in the grey mist of movement which moves not

and going". (lines 15-24).
\end{abstract}

At the end, as the poems start questioning evil and seek for evil home, now, Lawrence qualifies and declares his opinion and finds out the evil home, is "machines", and "wheels" as well. These are, according to Lawrence, the most dangerous things to the modern life. To be evil-soul, one will go, do, and be nothing, he will be vain, he is "grey", he is nothing of nothing, and his home will be not "anywhere", he is a poor man who has no "aristocratic individuality". In this part Lawrence shows his hostility to modern life and sorry for not being primitively and archaically lived. Considerably, Lawrence depicts the close connection with the old cultures considering them more natural and close to nature, and they are the nature itself.

Similar to the poem "Door", it ends with no very clear idea of the place of evil. It starts with, "evil is homeless", and ends with, "[it]has no home". So where is the home of evil? Yes, it is answered in the next poem, "What Then Is Evil?". The persona is still seeking for the place of the "evil".

To know "What Then Is Evil?" (Pinto and Roberts. p. 712), is more obvious in this poem. Lawrence says that "the principle of evil" begins when the "wheel" starts to appear.

According to Lawrence, the "wheel theory" of the heavens, where he probably refers to the Industrial Revolution of Victorian England. The "wheel theory" originally comes from Anaximander as" almost the very first of the ancient Greek 
thinkers, is supposed to have invented this wheel theory of the heavens in Ionia in the sixth century B.C." (Lawrence, 1995, p.82) Then Lawrence shows the form of the wheel concept theory of the heavenly bodies as:

\begin{abstract}
"These wheels are an ancient attempt to explain the orderly yet complex movement of the heavens. They are based on the first "scientific" duality which the pagans found in the universe, namely, the moist and the dry, the cold and the hot, air (or cloud) and fire". (Lawrence, 1995, p. 77)
\end{abstract}

The motion of the wheel of heavens is complex and this complexity comes from the many and sub-divisions of wheels "wheel within wheel, revolving differently".

The subject of "Evil" is continued in the poem "The Evil World-Soul" (Pinto and Rberts, pp. 712-13), Lawrence criticizes modern life and blames the modern man because he thinks that the imperfection of the world cannot come from god, but man who disturbs the world.

A direct reference to the Industrial Revolution, where, as described by Stephen Potter, "the hill itself is the mechanical world, that part of this world which is lived under imposed ideals. A world where everything is experienced exclusively in the head and talked to pieces there" (Potter, p. 28). This reflects the period of time that Lawrence lived in, which is under the effects of evil of the Industrial Revolution that most of the poets criticize, thinking that this revolution disturbs nature, souls and life.

The evil cannot be positive and active thing. But evil, according to Inge, must be "a spiritual power of evil which may be best designated as an evil world-soul" (Inge. P. 90). And according to Lawrence and his sources, there is another evil which is "machine".

For Lawrence everything has a soul, even the animate things. The "machine", is the main evil in the world, but it is possessed soul that is both individual and part of a larger evil "the world-soul". Nevertheless, "every man" who separated and thoughtful of self is also "evil".

Lawrence negatively describes the world-soul "machine" which is considered the worst thing invented by the man. 
العدد (37)

نيسان - ايرِل 2019

مجلة الفنون والندبوعاوم الإنسانيات ولاجتهاع

\section{Conclusions}

It is the modernity that ultimately was Antagonistic to D.H. Lawrence, it is corrupting human's life and thinking. It is engaging and enrolling human beings in its hub. It makes the world dark and grey colored. Paganism was so close to his feelings and thoughts. Nothing better in modernity just spoiling the beauty of nature and natural beauty. Lawrence thoughtfully aware of being modern. He like to be simple in his life in his thinking. And to be out of the world-soul, one must separate the "ego", and unconsciously lives his life.

\section{References}

1. Aldington, Richard. Portrait of A Genius, But . .., The Life of D.H. Lawrence 1885-1930. William Heinemann LTD, London,1950.

2. Ali, Abdullah Yusuf. www.qurantranslations.org . Chapter 2 The caw AlBaqarah Sura: verses,168-169. Italics are mine.

3. Ali, Abdullah Yusuf. www.qurantranslations.org. Chapter 18 The cave AlKahf Surah: verses,103-8.

4. Ali, Abdullah Yusuf. www.qurantranslations.org. Chapter 2 The Cow, AlBaqarah Surah:, verse, 110.

5. Burnet, John. Early Greek Philosophy. $3^{\text {rd }}$ edition, London: A\&C Black. 1920. www.casadosino.com.br.

6. Hamilton, Edith. Mythology, Timeless Tales of Gods and Heroes. New York, Poston: Grand Central Publishing, 1942.

7. Inge, William Ralph. The Philosophy of Plotinus. London: Longmans, Green And Co., 1918. www.forgottenbooks.com.

8. Karki, Ramesh. D.H. Lawrence As A Creative Critic: Ph.D. thesis. Dharwad:KurnatakUniv.shodhganga.inflibnet.ac.in/bitstream/10603/8394/1/01 _title.pdf, 2012, Ch.III.

9. Lawrence, D. H.. Complete Poems. Eds. Vivian De Sola Pinto and F. warren Roberts. New York: Penguin, 1993.

10.Lawrence, D.H. Apocalypse. Ed. Mara Kalnins. England: Penguin Books, 1995.

11.Potter, Stephen. D. H. Lawrence: A First Study. London: J. Cape \& H. Smith, 1930, p. 27. Italic is mine. 